\title{
Seismic Instrumentation Placement Recommendations Report
}

by

W. N. Kennedy

Westinghouse Savannah River Company

Savannah River Site

Aiken, South Carolina 29808

DOE Contract No. DE-AC09-96SR18500

This paper was prepared in connection with work done under the above contract number with the U.S.

Department of Energy. By acceptance of this paper, the publisher and/or recipient acknowledges the U.S. Government's right to retain a nonexclusive, royalty-free license in and to any copyright covering this paper, along with the right to reproduce and to authorize others to reproduce all or part of the copyrighted paper. 


\section{DISCLAIMER}

This report was prepared as an account of work sponsored by an agency of the United States Government. Neither the United States Government nor any agency thereof, nor any of their employees, makes any warranty, express or implied, or assumes any legal liability or responsibility for the accuracy, completeness, or usefulness of any information, apparatus, product, or process disclosed, or represents that its use would not infringe privately owned rights. Reference herein to any specific commercial product, process, or service by trade name, trademark, manufacturer, or otherwise does not necessarily constitute or imply its endorsement, recommendation, or favoring by the United States Government or any agency thereof. The views and opinions of authors expressed herein do not necessarily state or reflect those of the United States Government or any agency thereof.

This report has been reproduced directly from the best available copy.

Available to DOE and DOE contractors from the Office of Scientific and Technical Information, P. O. Box 62, Oak Ridge, TN 37831; prices available from (423) 576-8401.

Available to the public from the National Technical Information Service, U. S. Department of Commerce, 5285 Port Royal Road, Springfield, VA 22161. 


\section{DISCLAIMER}

Portions of this document may be illegible in electronic image products. Images are produced from the best available original document. 


\section{Seismic Instrumentation}

\section{Placement Recommendations Report}

\section{By}

W.N. Kennedy

September 9, 1998

Technical Reviewer:

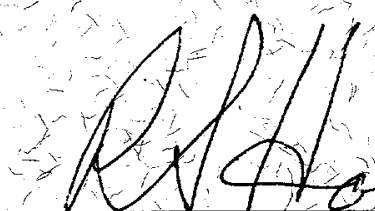

Richard S. Hoskins

Approved:

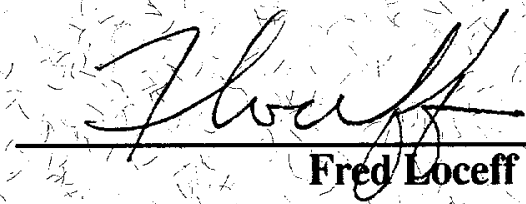

Project Engineering and Construction Division Structural Mechanies 


\section{Table of Contents}

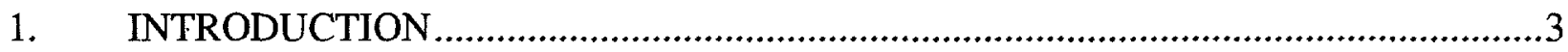

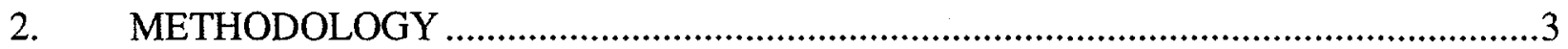

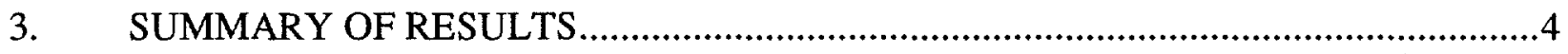

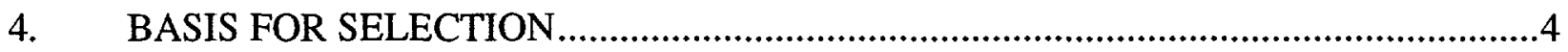

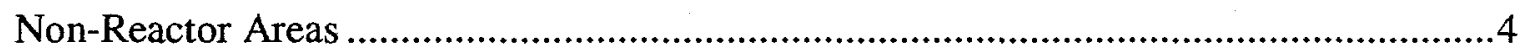

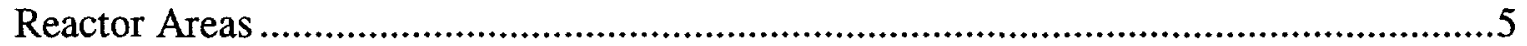

5. TABLE 1 - Nuclear and Hazardous PC3 Structures...................................................6

TABLE 2 - Building Type Codes .................................................................. 11 


\section{INTRODUCTION}

DOE Order 420.1, "Facility Safety", requires that facilities or sites with hazardous materials be provided with instrumentation or other means to detect and record the occurrences and severity of seismic events. These requirements assure that necessary records are available after an earthquake for evaluation purposes and to supplement other data to justify a facility restart or curtailing plant operations after an earthquake. This report documents the basis for the selection of Savannah River Site areas and existing facilities to be instrumented. The need to install instrumentation in new facilities such as the Actinide Packaging and Storage Facility, Commercial Light Water Reactor Tritium Extraction Facility and the Accelerator Production of Tritium Facility will be assessed separately.

\section{METHODOLOGY}

The selection methodology is largely judgmental, following the guidance of NRC Regulatory Guide 3.17, "Earthquake Instrumentation for Fuel Reprocessing Plants". The objectives in site selection were:

- $\quad$ achieve adequate distribution of measurement instruments across the developed parts of the site

- $\quad$ capture free field responses based on various water table depths and depths to bedrock.

- $\quad$ determine appropriate instrumentation placement in areas with active facilities in Performance Category 3 or 4 .

- $\quad$ capture responses of unusual structures or conditions, i.e., deeply embedded buildings or tall buildings that are predicted to have large amplification of the input motion.

The building review was performed using the total list of Performance Category 3 structures (Table 1, attached) from the SRS Structural Qualification Program (SQP). The Performance Category 3 structures constitute the total population of nuclear and hazardous facilities or structures to which the requirement of the Order is considered to be applicable.

General locations (e.g. the basemat or roof) of strong motion accelerographs within buildings are selected considering attributes such as; type of structural system, structure embedment, height of structure, and location of critical equipment. For example, all steel framed buildings and one story reinforced concrete structures on grade are excluded since the seismic response of these types of structures can be predicted with a high level of confidence. Specific locations within each area or structure will be included in the installation documents after a walkdown to determine the optimum location.

Inactive facilities and areas that do not have nuclear or hazardous (PC3) facilities do not require instrumentation, unless determined to be necessary to achieve adequate distribution of measurement capability across the developed parts of the site. 


\section{SUMMARY OF RESULTS}

Following are the recommendations for areas and structures to be provided with strong motion accelerographs (SMA). The rationale for these choices is provided in the Basis for Selection Section of this report.

It is concluded that strong motion accelerographs are not required in $\mathrm{B}, \mathrm{C}, \mathrm{E}, \mathrm{D}, \mathrm{M}, \mathrm{N}, \mathrm{R}, \mathrm{P}$ or T areas.

Instrumentation is to be provided in the following structures.

- A-area: The monitor already installed in the Science Laboratory (735A) is sufficient to represent A-Area.

- F-Area: Two SMAs are required:

- $\quad$ One monitor shall be located centrally within the F Tank Farm

- $\quad$ One shall be installed on the basemat of the Separations Building (221F).

- H-Area: Six SMAs shall be installed in H-Area:

- $\quad$ One SMA shall be installed on the H Tank Farm "new hill" proximate to Tank 50 at the edge of the berm.

- $\quad$ One "free field" SMA shall be installed near the base of the H Tank Farm hill.

- $\quad$ Three SMAs shall be installed in the 221-F Separations Building (basemat and 2 roof locations).

- $\quad$ One SMA shall be installed on the basemat in the Replacement Tritium Facility.

- K-Area: An SMA shall be installed in the 105K Reactor Building at elevation 0' floor slab. The need for this SMA is contingent upon completion of the K-Area Materials Storage (KAMS) project.

- L-Area: An SMA shall be provided in the 105L Reactor Building at elevation 0' floor slab.

- S-Area: The Defense Waste Processing Facility (221S) shall be monitored at two locations:

- $\quad$ One SMA on the basemat

- $\quad$ One SMA at roof elevation

- Other: An SMA is currently installed at the PAR Pond Dam. This will remain in place.

\section{BASIS FOR SELECTION}

\section{Non-Reactor Areas}

- A-Area: The most significant nuclear (PC3) structure in A-Area is SRTC (Building 773A). Current instrumentation exists in Building 735-A, which is within 500 feet of $773 \mathrm{~A}$. This is adequate for determination of response at 773A. The tallest structure in A Area is Building 703-A. Since 703A is PC2 instrumentation is not required.

- E-Area: Facilities and structures in E-Area (Solid Waste Disposal and Burial Ground) are all PC2. Response measurement is not required, however, the site can be considered to be bounded by the $\mathrm{F}$ and $\mathrm{H}$ area monitors. 
- F-Area: It is recommended that two existing facilities be instrumented. These will adequately represent all of $F$ area as it is currently developed. It is expected that additional instrumentation will be incorporated in the APSF buildings.

A surface monitor located centrally in the F Tank Farm, on the south side of F area, will measure motions representative of all tanks and the evaporator (242-16F).

The Separations Building $(221 \mathrm{~F})$, centrally located in $\mathrm{F}$ area, is the tallest nuclear structure in $\mathrm{F}$ area. Only one monitor is recommended at the subgrade basemat (Level 1) in Sections 3 or 15 (sections with most accessible areas for equipment installation). Because of similarity to the $\mathrm{H}$ Separations Building $(221 \mathrm{H})$ additional instrumentation for structural response at higher elevations within the $221 \mathrm{~F}$ building are not essential.

- H-Area: It is recommended that three $H$ area facilities be instrumented. These will cover the north and south extremities and center of $\mathrm{H}$ area.

A surface monitor located on the "new hill" in the $\mathrm{H}$ tank farm near the berm at Tank 50 is required to measure the response of the hill. A free field SMA installed at grade near the base of the hill shall be installed. This SMA covers the southern extremity of $\mathrm{H}$ area.

An SMA should be installed at the basemat of the Replacement Tritium Facility $(233 \mathrm{H})$. This will provide monitoring at the north extremity of $\mathrm{H}$ area and response of a deeply embedded structure.

The Separations Buildings $(221 \mathrm{H})$, centrally located in $\mathrm{H}$ area, is the tallest PC3 structure in $\mathrm{H}$ area. Three monitors are recommended. One shall be installed at the subgrade basemat (Level 1) in Sections 3 or 15 (sections with most accessible areas for equipment, installation). Two monitors should be installed on the roof (Level 5); one on Section 4 and one on Section 5. These are sections of greatly different stiffness and are expected to have different responses.

- S-Area: Two SMAs shall be installed in DWPF (Building 221S). As in the Separations buildings, one shall be on the basmat and a second shall be installed at the roof elevation of the concrete structure to measure building amplification.

- B-Area, D-Area, T-Area, N-Area and M-Area: These areas have no nuclear, hazardous or PC3 facilities, therefore monitoring is not required. There are no operating PC3 Facilities in M-Area.

\section{$\underline{\text { Reactor Areas }}$}

- C, P and R - Areas: There are no operating PC3 facilities at these sites. Therefore, structure monitoring is not required. An SMA is currently installed at PAR Pond. This will remain to provide monitoring at the southern extremity of the developed areas of SRS.

- K-Area: As part of the KAMS project, instrumentation shall be installed in the $105 \mathrm{~K}$ building at elevation $0^{\prime}$. Although $105 \mathrm{~K}$ is a tall building, response of the upper structure is 
not important since the upper structure response does not influence its only facility mission (KAMS), which is located at grade level.

- L-Area: A monitor should be installed at elevation 0' in the 105L Building between the Process Area and the Disassembly Basin. This will adequately cover current use (spent fuel storage in the basin) and potential future missions in the Process Area such as the Treatment and Storage Facility (TSF). A monitor is currently installed at the "gun" site, located to the south of and approximately equidistant from $\mathrm{L}$ and $\mathrm{P}$ reactors. This SMA will be relocated to L Reactor. 

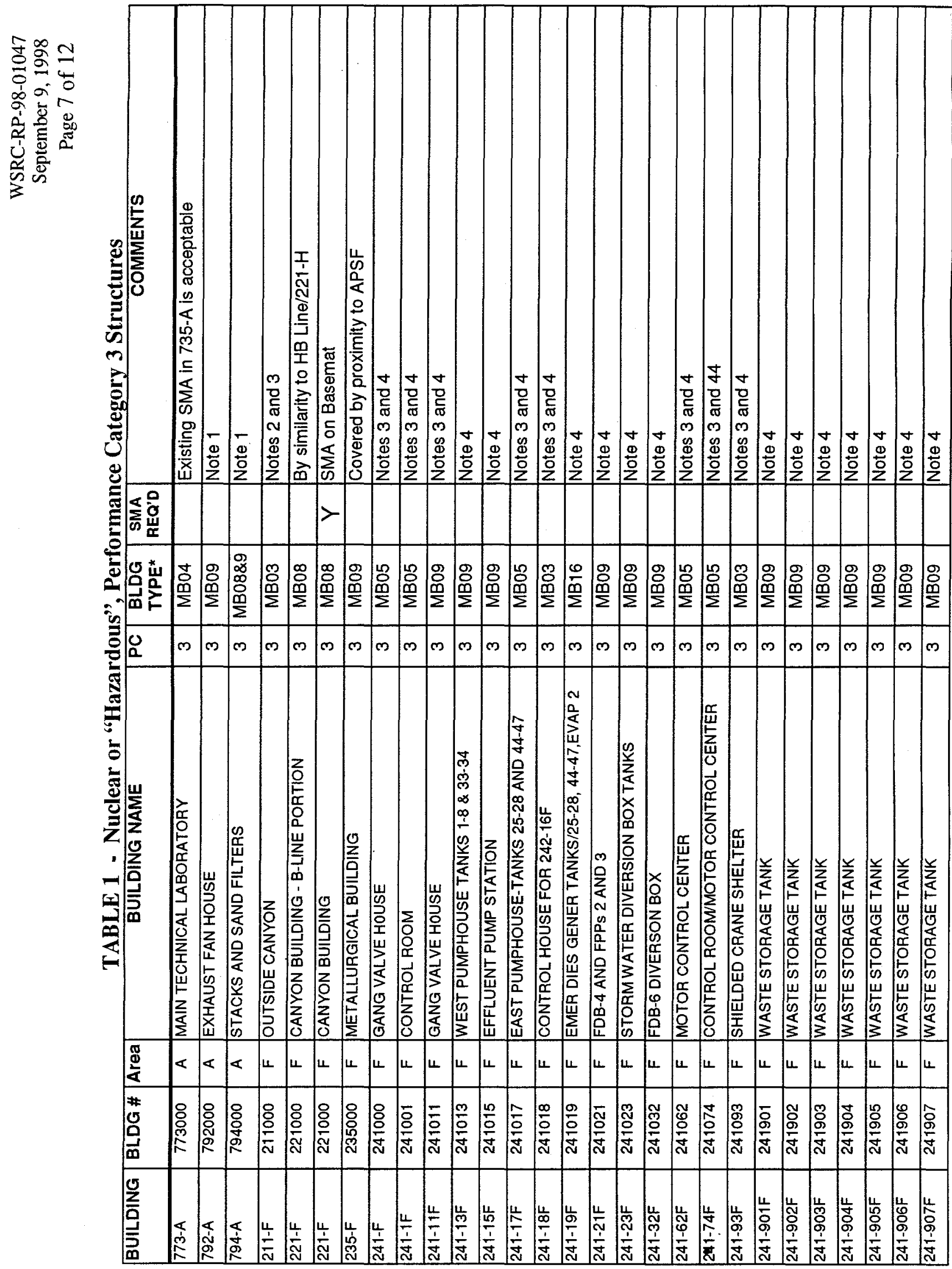
WSRC-RP-98-01047

\begin{tabular}{|c|c|c|c|c|c|c|c|}
\hline $241-908 \mathrm{~F}$ & 241908 & $F$ & WASTE STORAGE TANK & 3 & MB09 & & Note 4 \\
\hline $241-917 \mathrm{~F}$ & 241917 & $F$ & WASTE STORAGE TANK & 3 & MB09 & & Note 4 \\
\hline $241-918 \mathrm{~F}$ & 241918 & $F$ & WASTE STORAGE TANK & 3 & MB09 & & Note 4 \\
\hline $241-925 \mathrm{~F}$ & 241925 & $\bar{F}$ & WASTE STORAGE TANK & 3 & MB09 & & Note 4 \\
\hline $241-926 \mathrm{~F}$ & 241926 & $\bar{F}$ & WASTE STORAGE TANK & 3 & MB09 & & Note 4 \\
\hline $241-927 \mathrm{~F}$ & 241927 & $\bar{F}$ & WASTE STORAGE TANK & 3 & MB09 & & Note 4 \\
\hline $241-928 \mathrm{~F}$ & 241928 & $F$ & WASTE STORAGE TANK & 3 & MB09 & & Note 4 \\
\hline $241-933 \mathrm{~F}$ & 241933 & $F$ & WASTE STORAGE TANK & 3 & MB09 & & Note 4 \\
\hline $241-934 \mathrm{~F}$ & 241934 & $F$ & WASTE STORAGE TANK & 3 & MB09 & & Note 4 \\
\hline $241-944 \mathrm{~F}$ & 241944 & $F$ & WASTE STORAGE TANK & 3 & MB09 & & Note 4 \\
\hline $241-945 \mathrm{~F}$ & 241945 & $F$ & WASTE STORAGE TANK & 3 & MB09 & & Note 4 \\
\hline $241-946 \mathrm{~F}$ & 241946 & $\mathrm{~F}$ & WASTE STORAGE TANK & 3 & $\mathrm{MB09}$ & & Note 4 \\
\hline $241-947 \mathrm{~F}$ & 241947 & $F$ & WASTE STORAGE TANK & 3 & MB09 & & Note 4 \\
\hline $242-16 \mathrm{~F}$ & 242016 & $F$ & WASTE EVAPORATOR \#2 & 3 & MB09 & $Y$ & 1 free field SMA proximate to $242-16 \mathrm{~F}$ \\
\hline $247-\mathrm{F}$ & 247000 & 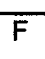 & NAVAL FUEL BUILDING & 3 & $\mathrm{MB03}$ & & Notes 3 and 5 \\
\hline $254-5 F$ & 254005 & $\bar{F}$ & DIESEL GENERATORS & 3 & MB09 & & Note 2 \\
\hline $291-\mathrm{F}$ & 291000 & $\mathbf{F}$ & F CANYON STACK & 3 & MB09 & & Note 2 \\
\hline $292-\mathrm{F}$ & 292000 & $F$ & F CANYON EXHAUST FAN HOUSE & 3 & MB09 & & Note 2 \\
\hline $292-\mathrm{F}$ & 292000 & $\mathbf{F}$ & CANYON EXHAUST FAN HOUSE & 3 & MB09 & & Note 2 \\
\hline $292-1 \mathrm{~F}$ & 292001 & $F$ & VESSEL VENT FAN HOUSE & 3 & MB09 & & Note 2 \\
\hline $292-2 F$ & 292002 & $\mathbf{F}$ & FAN HOUSE & 3 & MB09 & & Note 5 \\
\hline $293-F$ & 293000 & $F$ & STACK MONITOR & 3 & MB08 & & Note 5 \\
\hline 294-F & 294000 & $\mathbf{F}$ & CANYON EXHAUST SAND FILTER & 3 & MB09 & & Note 2 \\
\hline $294-1 F$ & 294001 & $F$ & ADDED CANYON EXHAUST SAND FILTER & 3 & $\mathrm{MB09}$ & & Note 2 \\
\hline 294-2F & 294002 & $F$ & SAND FILTERS & 3 & MB09 & & Note 5 \\
\hline $772-\mathrm{F}$ & 772000 & $\bar{F}$ & CONTROL LABORATORY & 3 & MB04 & & Note 2 \\
\hline $772-1 \mathrm{~F}$ & 772001 & $F$ & PRODUCTION CONTROL FACILITY & 3 & MB04 & & Note 2 \\
\hline $772-4 \mathrm{~F}$ & 772004 & $\bar{F}$ & AIRBORNE RADIATION REMOVAL & 3 & MB04 & & Note 2 \\
\hline $907-1 \mathrm{~F}$ & 907001 & $F$ & STORM WATER DIVERSION GATES & 3 & MB09 & & Note 4 \\
\hline $221-\mathrm{H}$ & 221000 & $\mathrm{H}$ & H CANYON/HB LINE & 3 & MB08 & $\mathrm{Y}$ & Note 3 SMA; 1 at basemat, 2 at Level 5 \\
\hline $232-\mathrm{H}$ & 232000 & $\overline{\mathrm{H}}$ & MANUFACTURING BUILDING & 3 & MB10 & & Note 6 \\
\hline
\end{tabular}




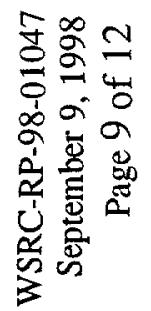

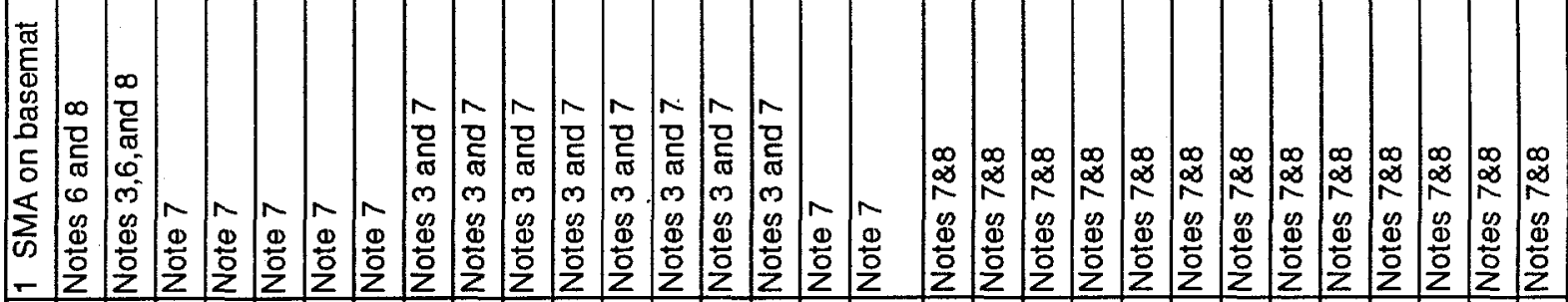

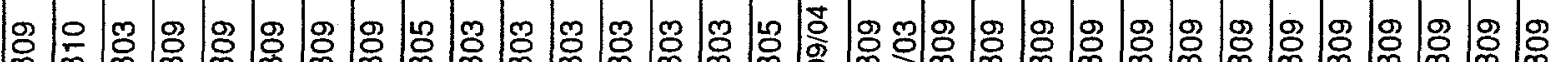

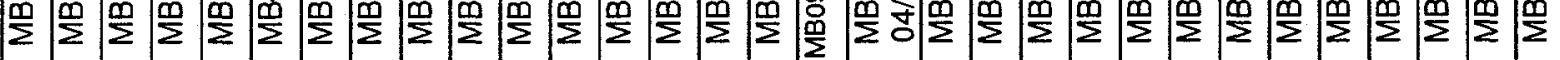

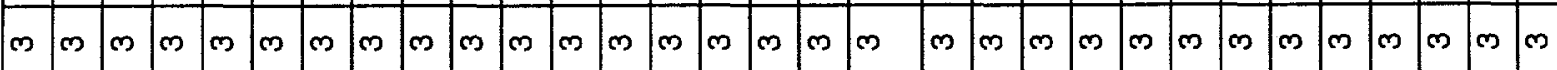

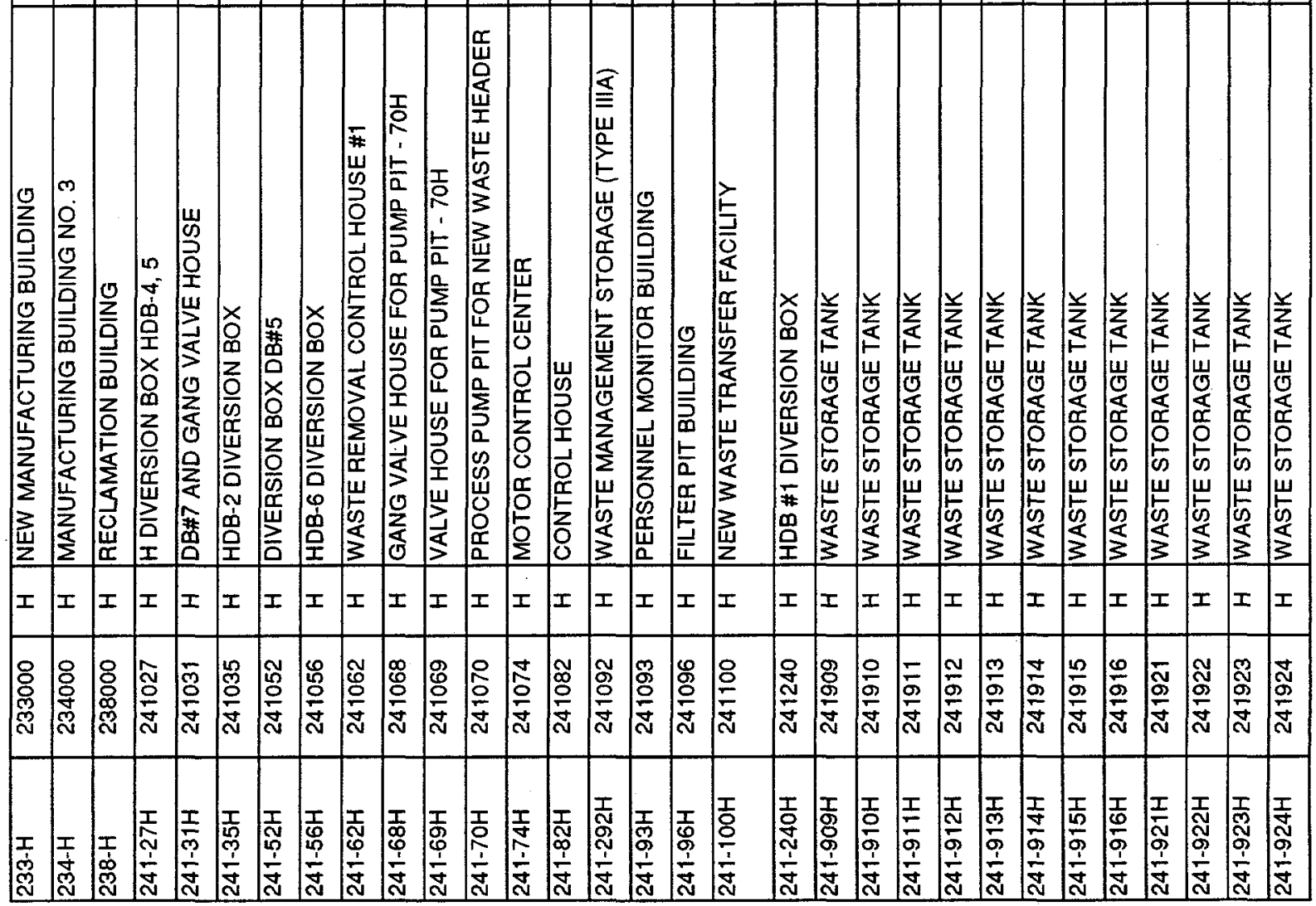


WSRC-RP-98-01047 September 9, 1998

Page 10 of 12

\begin{tabular}{|c|c|c|c|c|c|c|c|}
\hline $241-929 \mathrm{H}$ & 241929 & $\mathrm{H}$ & WASTE STORAGE TANK & 3 & MB09 & & Notes 7\&8 \\
\hline $241-930 \mathrm{H}$ & 241930 & $\mathrm{H}$ & WASTE STORAGGE TANK & 3 & MB09 & & Notes 7\&8 \\
\hline $241-931 \mathrm{H}$ & 241931 & $\mathrm{H}$ & WASTE STORAGE TANK & 3 & MB09 & & Notes 788 \\
\hline $241-932 \mathrm{H}$ & 241932 & $\mathrm{H}$ & WASTE STORAGE TANK & 3 & MB09 & & Notes 788 \\
\hline $241-935 \mathrm{H}$ & 241935 & $\mathrm{H}$ & WASTE STORAGE TANK & 3 & MB09 & & Notes $7 \& 8$ \\
\hline $241.936 \mathrm{H}$ & 241936 & $\mathrm{H}$ & WASTE STORAGE TANK & 3 & MB09 & & Notes 788 \\
\hline $241.937 \mathrm{H}$ & 241937 & $\mathrm{H}$ & WASTE STORAGE TANK & 3 & MBO9 & & Notes 788 \\
\hline $241-938 \mathrm{H}$ & 241938 & $\mathrm{H}$ & WASTE STORAGE TANK & 3 & MB09 & & Note 7 \\
\hline $241.939 \mathrm{H}$ & 241939 & $\mathrm{H}$ & WASTE STORAGE TANK & 3 & MBO9 & & Note 7 \\
\hline $241.940 \mathrm{H}$ & 241940 & $\mathrm{H}$ & WASTE STORAGE TANK & 3 & MB09 & & Nate 7 \\
\hline $241.941 \mathrm{H}$ & 241941 & $\mathrm{H}$ & WASTE STORAGE TANK & 3 & MB09 & & Note 7 \\
\hline $241-942 \mathrm{H}$ & 241942 & $\mathrm{H}$ & WASTE STORAGE TANK & 3 & MB09 & & Note 7 \\
\hline $241-943 \mathrm{H}$ & 241943 & $\mathrm{H}$ & WASTE STORAGE TANK & 3 & MB09 & & Note 7 \\
\hline $241-948 \mathrm{H}$ & 241948 & $\mathrm{H}$ & WASTE STORAGE TANK & 3 & MB09 & & Note 7 \\
\hline $241-949 \mathrm{H}$ & 241949 & $\mathrm{H}$ & WASTE STORAGE TANK & 3 & $\mathrm{MB} 09$ & & Note 7 \\
\hline $241-950 \mathrm{H}$ & 241950 & $\mathrm{H}$ & WASTE STORAGE TANK & 3 & MBO9 & $\mathrm{Y}$ & Note 2 SMA; 1 on new hill near tank 50,1 at base of hill \\
\hline $241-951 \mathrm{H}$ & 241951 & $\mathrm{H}$ & WASTE STORAGE TANK & 3 & MB09 & & Note 7 \\
\hline $242-16 \mathrm{H}$ & 242016 & $\mathrm{H}$ & WASTE EVAPORATOR \#2 & 3 & MB09 & & Note 7 \\
\hline $244-\mathrm{H}$ & 244000 & $\mathrm{H}$ & RECEIVING BASIN FOR OFFSITE FUELS & 3 & MB04 & & Note 8 \\
\hline $254-5 \mathrm{H}$ & 254005 & $\mathrm{H}$ & DIESEL GENERATOR & 3 & MB09 & & Note 6 \\
\hline $254-8 \mathrm{H}$ & 254008 & $\mathrm{H}$ & STANDBY DIESEL GENERATOR & 3 & MB16 & & Note 6 \\
\hline $254-9 \mathrm{H}$ & 254009 & $\mathrm{H}$ & STANDBY GENERATOR & 3 & MB16 & & Note 6 \\
\hline $291-\mathrm{H}$ & 291000 & $\mathrm{H}$ & H CANYON STACK & 3 & MB08 & & Note 6 \\
\hline $292-\mathrm{H}$ & 292000 & $\mathrm{H}$ & CANYON EXHAUST FAN HOUSE & 3 & MB09 & & Note 6 \\
\hline $292-1 \mathrm{H}$ & 292001 & $\mathrm{H}$ & VESSEL VENT FAN HOUSE & 3 & MB08 & & Note 6 \\
\hline $292-2 \mathrm{H}$ & 292002 & $\mathrm{H}$ & FAN HOUSE BUILDING & 3 & $\mathrm{MB03}$ & & Note 6 \\
\hline $292-3 \mathrm{H}$ & 292003 & $\mathrm{H}$ & STACK MONITORING EQUIPMENT BUILDING & 3 & MB05 & & Note 6 \\
\hline $294-\mathrm{H}$ & 294000 & $\mathrm{H}$ & H CANYON EXHAUST FILTERS & 3 & MB09 & & Note 6 \\
\hline 294-1H & 294001 & $\mathrm{H}$ & ADDED CANYON SAND FILTERS & 3 & MB09 & & Note 6 \\
\hline $295-\mathrm{H}$ & 295000 & $\mathrm{H}$ & STACK FOR BUILDING 232-F\&H & 3 & MB08 & & Note 8 \\
\hline $296-\mathrm{H}$ & 296000 & $\mathrm{H}$ & STACK FOR BUILDING 234-H & 3 & MB08 & & Note 8 \\
\hline $297-\mathrm{H}$ & 297000 & $\mathrm{H}$ & STACK NO. 2 FOR BUILDING 232-H & 3 & MB08 & & Note 8 \\
\hline $298-\mathrm{H}$ & 298000 & $\mathrm{H}$ & POLLUTION CONTROL STACK FOR BLDG 238-H & 3 & MB05 & & Note 8 \\
\hline $299-1 \mathrm{H}$ & 299001 & $\mathrm{H}$ & EMERGENCY DIESEL GENERATOR FOR 299-H & 3 & MB16 & & Note 6 \\
\hline
\end{tabular}




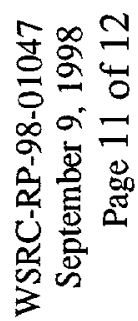

足

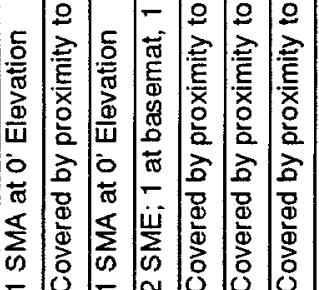

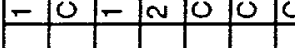

$>$

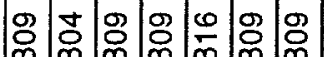

$\sum_{\Sigma}^{\infty} \sum \sum \sum \frac{\mathscr{D}}{\Sigma} \sum \frac{\mathscr{m}}{\Sigma} \sum^{\infty}$

の m

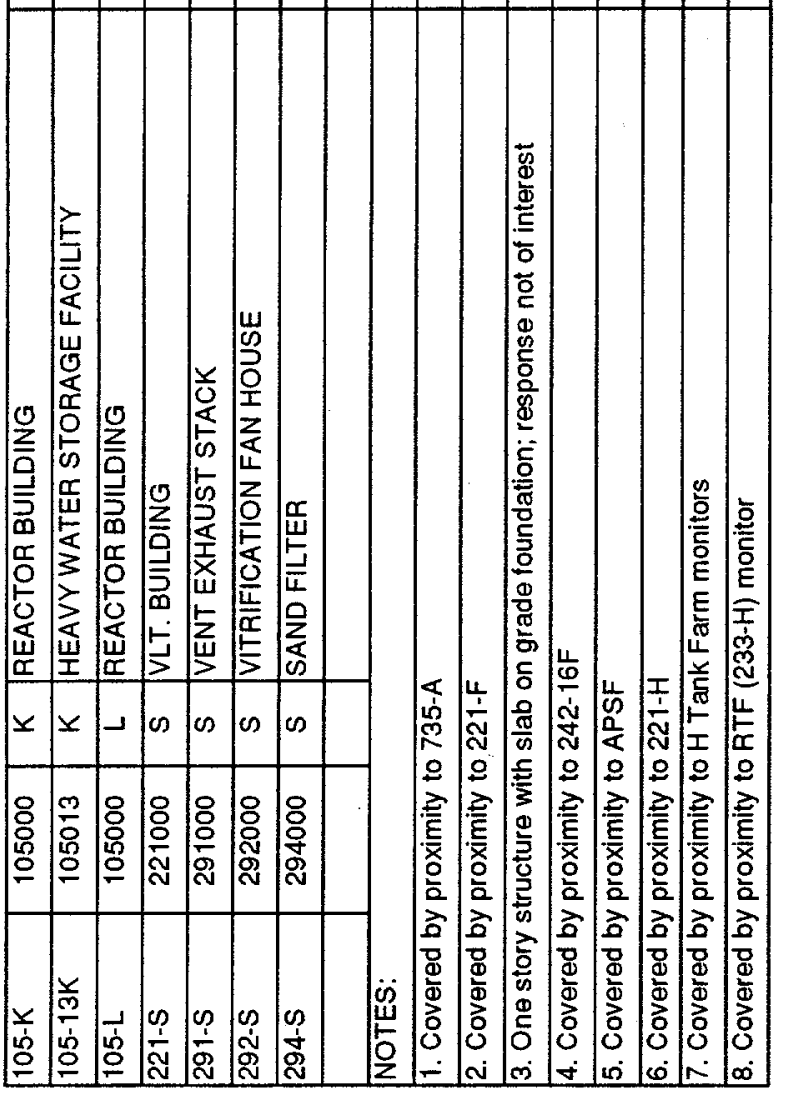




\begin{tabular}{|l|l|}
\hline \multicolumn{2}{|c|}{ Table 2 - Building Types } \\
\hline Code & \multicolumn{1}{|c|}{ Model Building Type } \\
\hline MB01 & Wood, Light Frame \\
\hline MB02 & Wood, Commercial and Industrial \\
\hline MB03 & Steel Moment Frame \\
\hline MB04 & Steel Braced Frame \\
\hline MB05 & Steel Light Frame \\
\hline MB06 & Steel Frame with Concrete Shear Walls \\
\hline MB07 & Steel Frame with Infill Shear Walls \\
\hline MB08 & Concrete Moment Frame \\
\hline MB09 & Concrete Shear Walls \\
\hline MB10 & Concrete Frame with Infill Shear Walls \\
\hline MB11 & Precast/Tilt-Up Concrete Walls with Lightweight Flexible Diaphragm \\
\hline MB12 & Precast Concrete Frames with Concrete Shear Walls \\
\hline MB13 & Reinforced Masonry Bearing Walls with Wood or Metal Deck Diaphragms \\
\hline MB14 & Reinforced Masonry Bearing Walls with Precast Concrete Diaphragms \\
\hline MB15 & Unreinforced Masonry Bearing Wall Buildings \\
\hline MB16 & Other - does not fit listed types; e.g. self-contained diesel generator unit \\
\hline
\end{tabular}

